\title{
Oocyte Cryopreservation in Domestic Animals and Humans: Principles, Techniques and Updated Outcomes
}

\author{
Theerawat Tharasanit ${ }^{1,2, *}$ [i] and Paweena Thuwanut ${ }^{3}$ \\ 1 Department of Obstetrics, Gynecology and Reproduction, Faculty of Veterinary Science, \\ Bangkok 10330, Thailand \\ 2 Veterinary Clinical Stem Cells and Bioengineering Research Unit, Chulalongkorn University, \\ Bangkok 10330, Thailand \\ 3 Department of Obstetrics and Gynecology, Division of Reproductive Medicine, Faculty of Medicine, \\ Chulalongkorn University, Bangkok 10330, Thailand; paweena.thuwanut@gmail.com \\ * Correspondence: Theerawat.t@chula.ac.th
}

check for updates

Citation: Tharasanit, T.; Thuwanut, P. Oocyte Cryopreservation in Domestic Animals and Humans: Principles, Techniques and Updated Outcomes. Animals 2021, 11, 2949. https:// doi.org/10.3390/ani11102949

Academic Editors: Daniela Bebbere and Sara Succu

Received: 7 September 2021

Accepted: 6 October 2021

Published: 13 October 2021

Publisher's Note: MDPI stays neutral with regard to jurisdictional claims in published maps and institutional affiliations.

Copyright: (C) 2021 by the authors. Licensee MDPI, Basel, Switzerland. This article is an open access article distributed under the terms and conditions of the Creative Commons Attribution (CC BY) license (https:/ / creativecommons.org/licenses/by/ $4.0 /)$.
Simple Summary: Oocyte cryopreservation is the most powerful technique for preserving the genetic potential of individual females. However, the recent outcomes of this technology in terms of viability, fertilizing ability, embryo development and pregnancy remain poor. The high sensitivity of the oocytes to freezing has been correlated with the profound dynamics of oocyte structures and functions. As a result, cryoinjury inevitably occurs at several cellular levels, which is indeed detrimental to cell viability and subsequent development. Advancement in the improvement of freezing technology via modifications to freezing technique and development of novel cryodevices plays a central role in mitigating cryoinjury and efficiently empowering the outcomes of oocyte cryopreservation. However, empirical study and optimizations of the techniques are generally required for cryopreservation of oocytes from particular species.

Abstract: Oocyte cryopreservation plays important roles in basic research and the application of models for genetic preservation and in clinical situations. This technology provides long-term storage of gametes for genetic banking and subsequent use with other assisted reproductive technologies. Until recently, oocytes have remained the most difficult cell type to freeze, as the oocytes per se are large with limited surface area to cytoplasm ratio. They are also highly sensitive to damage during cryopreservation, and therefore the success rate of oocyte cryopreservation is generally poor when compared to noncryopreserved oocytes. Although advancement in oocyte cryopreservation has progressed rapidly for decades, the improvement of cryosurvival and clinical outcomes is still required. This review focuses on the principles, techniques, outcomes and prospects of oocyte cryopreservation in domestic animals and humans.

Keywords: animal; cryopreservation; human; oocyte

Assisted reproductive technologies, such as artificial insemination, in vitro fertilization and cryopreservation play important roles in basic research and the application of models for genetic preservation and in clinical situations. Of the technologies available, gamete preservation has increasingly gained attention because it provides long-term storage of gametes for genetic banking. The cryopreservation of somatic cells and sperm has been well adapted, and the success rate in terms of viability and functions is generally high. However, oocytes have limited surface area/cytoplasm ratio, which render them the most difficult cells to freeze. This review focuses on the principles, techniques, outcomes and prospects of oocyte cryopreservation in domestic animals, including small (dog and cat), medium-sized (pig) and large animals (cow and horse). Nonhuman primates and humans are also included in the review. 


\section{General Aspects of Oocyte Cryopreservation}

The success of oocyte cryopreservation was first reported in the 1970s [1,2]. It has become clear that cryopreservation processes inevitably induce cellular and molecular changes that render poor fertilization rate and embryo development [3-5]. Controlled-rate slow cryopreservation and vitrification are the two freezing techniques that are clinically applied to oocyte cryopreservation in animals and humans. Slow freezing principally requires a relatively low concentration of cryoprotective agent (CPA), applied with sufficiently slow cooling/freezing rates to ensure a fine control over various factors (i.e., thermal shock) that contribute to cell damage [6]. By gradually decreasing the rate of supra- to sub-zero cooling, the CPA allows adequate cellular dehydration leading to minimal intracellular ice $[6,7]$. At subzero temperatures, the essential step of slow freezing is so-called "seeding", a process which induces extracellular ice formation by converting the unfrozen solution to a hyperosmotic state, inducing cell dehydration [8]. With a slow-freezing approach, intracellular water is converted into a glassy phase composed of small intracellular ice crystals [7]. Therefore, super-rapid warming is required for the thawing process to avoid extensive crystallization and cell damage [7]. In contrast, vitrification requires an extremely high concentration of CPA and also an ultrafast freezing rate [9]. During cryopreservation, cells are exposed to several unfamiliar environments, such as chemical toxicity, osmotic changes and low temperature, all of which potentially disrupt cell functions and result in cell death $[4,10,11]$. Indeed, several factors, including species differences, age and fertility of oocyte donor, stage of oocyte maturation and cryopreservation protocols, have been reported to affect the success of oocyte cryopreservation. Notably, a large variation in oocyte physiology in particular animals cause difficulties in obtaining a consensus on freezing protocols. In some species, such as porcines, high contents of lipids have been claimed to cause poor oocyte freezing ability $[12,13]$. Thus, the development of freezing techniques and outcomes in terms of fertilization rate, embryo development and pregnancy rate following embryo transfer have been variable among species and laboratories. This aspect is very important for species for which oocytes are not readily available, such as wild species. In this case, anatomically and physiologically related domestic species are logically used to develop suitable cryopreservation techniques. Likewise, the availability of human oocytes for experimental purposes is very limited due to ethical reasons. According to similarities in reproductive physiology between nonhuman primates and humans, such as menstrual cycle length and hormonal profiles in rhesus macaques, nonhuman primates have been important in reproductive biology research during the last two decades [14]. Studies on nonhuman primates as human models in the fields of reproductive biology, reproductive medicine and assisted reproductive technology (ART) have been conducted for decades [14]. For oocyte cryopreservation, research studies using nonhuman primates were established in the late 1980s to early 1990s [15,16] where the principle of osmotic shock being responsible for oocyte quality was agreed [17]. In humans, the first achievement of pregnancy after oocyte cryopreservation was reported in 1986 [18]. However, limited success in oocyte cryopreservation discouraged this technique in routine clinical application for several years [19]. In the 2000s, knowledge of cryobiology by vitrification introduced the possibility of effectively cryopreserving functional oocytes, leading to revolutions in oocyte cryopreservation programs in clinical practice [20]. This was supported by a large randomized clinical trial on oocyte donation that revealed that vitrified oocyte quality was not inferior to fresh oocytes in terms of pregnancy outcomes [21]. Later, oocyte cryopreservation has become a fascinating alternative option for women who attempt in vitro fertilization (IVF) or fertility preservation programs [22]. Benefits of oocyte cryopreservation include increased flexibility to preserve (1) excess oocytes eventually present in each subsequent IVF cycle; (2) fertility in women who are at risk of infertility caused by chemotherapy/radiotherapy/premature ovarian insufficiency (POI) or who prefer to postpone childbearing and prevent age-related fertility decline ( $>36$ years old) $[20,22]$. Additionally, oocyte cryopreservation technology could facilitate some advantages in routine IVF programs, such as (1) reducing the number of controlled ovarian stimulation cycles in 
infertile patients; (2) delaying fresh embryo transfer programs aimed at preventing ovarian hyperstimulation syndrome (OHSS) or to optimize artificial endometrial preparation (AEP) and (3) offering options for infertile couples with religious objections to embryo cryopreservation $[5,23]$. Consequently, oocyte cryopreservation is now considered a promising tool that could motivate women or infertile patients to preserve their genetic materials for medical or nonmedical reasons.

\section{Principles of Oocyte Cryopreservation}

Oocyte cryopreservation is an important tool for preserving germ cells for subsequent uses such as fertilization, as cytoplasts for somatic cell nuclear transfer, and also for genome banking for patients and valuable animal species. However, oocytes are very susceptible to damage during cooling and cryopreservation. Furthermore, oocytes also have a relatively low membrane permeability to water and cryoprotectants [24]. Although the optimization of freezing procedures has resulted in improvements in oocyte quality, oocyte structures such as the plasma membrane [25] and cytoskeleton [26,27] have been shown to be very sensitive to cryoinjury, frequently resulting in cellular disruption and cell death. Several factors have been shown to influence the outcome of oocyte cryopreservation, such as the stage of oocyte maturation during freezing, types of cryoprotectants used and freezing techniques. Immature oocytes are arrested at prophase I (germinal vesicle stage) where the condensed chromatins are protected within the nuclear membrane. Following maturation, the oocytes complete nuclear and cytoplasmic maturation promptly for fertilization and further embryonic development. Results obtained from the cryopreservation of immature and mature oocytes have been contradictory and variable among species and laboratories. In principle, the cryopreservation of immature oocytes is beneficial over mature oocytes, as they do not have a cold-sensitive meiotic spindle. However, cryopreservation processes per se disrupt oocyte structure and the signals responsible for oocyte maturation. Therefore, maturation and fertilization rates of frozen-thawed oocytes are generally poor when compared to noncryopreserved oocytes. These poor results of oocyte cryopreservation have been reported to involve cryoinjury at several levels, such as excessive formation of lethal intracellular ice [28], chromosome abnormality [29], disturbance of hyperosmotic stress [30,31], disruption of actins and microtubules [32] and zona pellucida hardening [33]. More recently, studies have also indicated that cryopreservation induces changes in gene and protein expressions [34-37].

\section{Cryoprotective Agents}

Cryoprotective agents (CPAs) are chemical substances generally used to protect from cryoinjury during cryopreservation. Notably, the actions of CPAs are variable according to the type used and other factors, such as temperatures and cell type [38]. The CPAs are broadly classified as penetrating and nonpenetrating CPAs according to their ability regarding cell membrane permeability.

Penetrating CPAs are generally organic compounds that permeate passively through the plasma cell membrane. These include glycerol, ethylene glycol, propylene glycol (1,2-propanediol), dimethyl sulfoxide, methanol and butanediol. Once the CPA enters the intracellular fluid, it replaces water and interferes in the hydrogen bonding between water molecules, thereby reducing intracellular ice formation. In addition, penetrating CPAs also help to increase the hydration status of cells during cooling in order to prevent the excessive accumulation of cellular electrolytes. Penetrating CPAs have, in general, a molecular weight typically less than 100 Daltons and with high amphiphilic properties [39]. However, excessive accumulation of penetrating CPAs also results in an increased cellular toxicity. Theoretically, intact mammalian cells should tolerate volume excursion, since these cells must be exposed to the hypertonic CPA solution $[17,40]$. This phenomenon leads to the difference in water activity between intra- and extra-cellular compartments [40]. If mammalian cells exceed the limitation of volume excursion at subzero temperatures, cell damage or apoptosis occur as a consequence of osmotic stress or osmotic shock [17,40]. It is 
worth noting that particular cell types will require a specific type and optimal concentration of CPA in order to protect them from cryoinjury during cooling and cryopreservation.

Nonpenetrating CPAs are another type of CPA commonly added to the freezing medium. These CPAs are high in molecular weight and often have high hydrophilicity. In past decades, researchers have applied nonpenetrating CPAs during cryopreservation in order to protect cells from high osmotic stress and CPA toxicity. The common nonpenetrating CPAs are polyvinylpyrrolidone, polyethylene glycol, and sugars such as sucrose and trehalose [41,42]. A combination of penetrating and nonpenetrating CPAs is the most practical way to reduce cryoinjury during cryopreservation [43-45]. Molecular dynamics of cell membranes (lipid bilayers) stimulated by CPAs have been regulated in various mechanisms which are dependent upon the types of CPAs. For example, dimethyl sulfoxide has a more efficient capability to diffuse across the phospholipid bilayers compared with the other CPAs. However, high concentrations of dimethyl sulfoxide might cause the thinning of lipid bilayers, thereby leading to the complete destruction of lipid bilayers or the loss of membrane permeability [38]. In contrast to the polyol CPAs (i.e., sugar alcohol), their ability to form hydrogen bonds with lipid bilayers could minimize the lipid bilayers-thinning effect [38]. Furthermore, another proposed mechanism is such as colligative property (alteration: phase of diagram in solution) which has been observed in glycerol. This mechanism could buffer salt $(\mathrm{NaCl})$ concentration and alter crystalline solid forming occurred during cryopreservation process [38].

\section{Cryopreservation Techniques}

Techniques for the cryopreservation of oocytes, as well as of sperm and embryos, are generally classified as controlled-rate slow freezing and "ice-free" vitrification. Conventional slow freezing requires a programable freezer that can substantially control the optimal freezing rate. During cooling, the temperature is gradually decreased to below the freezing point where ice is formed. However, ice formation occurs in the extracellular and intracellular regions. Excessive ice formation within cells, especially intracellular ice formation, disrupts cell structure and function, which results in apoptosis or cell death. The initiation of the outgrowth of extracellular ice formation via seeding ice crystals is generally performed to mitigate the excessive formation of ice during supercooling. At this stage, extracellular ice is formed and the osmolarity of the extracellular fluid is also gradually increased. The oocytes will be in the dehydrated stage during freezing due to the unfrozen intracellular water flowing out to balance the osmolarity. As the oocytes are the largest cells and have low membrane permeability to cryoprotectants, most cryopreservation requires a freezing rate that is slow enough for sufficient CPA permeability. However, oocyte membrane permeabilities to CPA and cryotolerant have been demonstrated to differ among species. Although theoretical models can be used to predict the optimal freezing rate, empirical study is frequently required to test the freezing protocols prior to use. If the temperature is reduced too rapidly, excessive intracellular ice will be formed. In contrast, oocytes will undergo severe dehydration if the freezing rate is too slow. Therefore, the optimal freezing rate is the slow process that achieves a balance between adequate cellular dehydration and minimal intracellular ice formation. By using this technique, low concentrations of CPA are generally required, thus minimizing osmotic shock and CPA toxicity.

In contrast to slow freezing, vitrification allows the rapid transition from a liquid phase to a glasslike stage or water solidification. Vitrification is another promising technique for living cell cryopreservation [19]. Principally, the definition of vitrification is a "process of glass solidification of a liquid or water-based solution without ice crystal formation" [46]. To achieve this result, high concentrations of CPAs (both permeable and nonpermeable CPAs) are loaded onto living cells before deep freezing in liquid nitrogen $[19,47]$. However, this procedure causes extreme osmotic stresses and chemical toxicity $[19,47]$. Different devices can be modified for efficient vitrification such as open-pulled straw [48], solid surface [3], cryoloop [49], electron microgrids [50] and cryotop [51]. 


\section{Outcome following Oocyte Cryopreservation}

Oocyte cryopreservation is a mostly successful procedure in laboratory animals, especially in the mouse, due to the fact that the oocytes are quite tolerant to cold stress [52]. Additionally, the technology of embryo production from frozen oocytes is well developed in this species [53]. In the mouse, oocyte cryopreservation is very useful technique for storing the genetics of specific breeds such as gene-modified animals. Unlike mouse oocytes, knowledge on mechanism of oocyte maturation in other animals is still lacking. Although the oocytes of larger species are relatively more sensitive to cold stress compared to those of the mouse, live offspring have been born from medium to large size domestic animals, including cat [54,55], pig [56], cows [57-59] and horse [60,61], as well as humans [18].

\subsection{Ruminants (Bovine and Ovine)}

In ruminants, oocyte cryopreservation was first reported in the 1900s, indicating the possibility of embryo development and pregnancy following oocyte cryopreservation [57,62]. The previous findings also suggested that the mature oocytes were highly sensitive to cooling to lower than $10^{\circ} \mathrm{C}$, even without cryopreservation [63]. However, both stages of maturation (immature and mature stages) could be slow-cryopreserved with no significant difference in terms of cleavage and blastocyte formation rates (58\% vs. $60 \%$ and $7 \%$ vs. $12 \%$, respectively) [64]. The high chilling sensitivity of matured bovine oocytes led to the development of vitrification using electron microgrids [50]. In recent years, vitrification of bovine oocytes has gained interest. Indeed, full-term development following transfer of embryos derived from frozen-thawed or vitrified immature oocytes has been reported $[58,59,64,65]$. Development of vitrification technology for bovine oocytes has made much progress, probably because vitrification requires less equipment, is less time-consuming and is much more cost-effective compared to conventional slow freezing. Several devices have been applied efficiently in the vitrification of bovine oocytes, such as cryoloops [66], open-pulled straws [48] metal solid surfaces [3], cryotops [67], nylon mesh [68] and silk fibroin sheets [69]. The improvement in fertilization and blastocyst rates of vitrified oocytes has attributed to the extremely high cooling and warming rates and the use of a minimum-volume approach $[48,70,71]$. The latter technique, The Cryotop ${ }^{\circledR}$ system, requires less than $0.1 \mu \mathrm{L}$ volume and can reach a cooling of up to $23,000{ }^{\circ} \mathrm{C} / \mathrm{min}$ and a warming at up to $42,000{ }^{\circ} \mathrm{C} / \mathrm{min}$. This system yields cleavage rates of $59.5 \%$ and blastocyst rates of $22.9 \%$. However, this is still lower than fresh control $(77.6 \%$ and $44.7 \%$, respectively) [71]. Using minimum-volume vitrification, silk fibroin, nylon mesh and cryotop yielded similar blastocyst rates (approximately 25\%) comparing unfavorably to controls (40.6\%) [69]. Information regarding cryopreservation in sheep and goat is relatively limited compared to that in cows. While the outcome in terms of embryo development following conventional slow freezing is poor [72,73], most research has adapted the vitrification technologies from other species aimed at reducing cryoinjuries [72,74-80]. However, blastocyst development is still poor, ranging from $0 \%$ to $12.5 \%[75-77,81]$.

\subsection{Horse}

Research into the development of oocyte cryopreservation of equine oocytes has been limited, due principally to the difficulty in obtaining oocytes from equine ovaries. Equine ovaries can be obtained from local abattoirs in some countries or from live donors using ovum pickup (OPU) [82,83]. However, the relatively poor responses of equine ovaries to routine gonadotropin preparation [84] and also the poor oocyte recovery following OPU are due to the finding that equine cumulus cells adhere strongly to the follicular wall [85]. More importantly, conventional in vitro fertilization failed to fertilize the matured oocytes, and intracytoplasmic sperm injection (ICSI) is the only meaningful way of fertilizing the oocytes [86]. Variable results in meiotic competence and embryo development for cryopreserved equine oocytes are affected by several factors, such as the stage of maturation and the freezing medium and technique used. Information on the efficiency of slow freezing for equine oocytes is limited. Comparing the two techniques, open-pulled 
straw vitrification of immature oocytes yielded significantly greater maturation rates than slow freezing [32]. In addition, cryopreservation also induced alterative changes in mitochondrial morphology [87], cytoskeleton and chromatin configuration [32,88]. In the early phase of technological development, maturation rates of vitrified immature oocytes were poor (less than 20\%) [87,89]. Recently, results have been much improved and range from $33.3 \%$ to $54 \%$ [61,90-93]. Following fertilization via ICSI, the vitrified-warmed oocytes could develop into cleavage- and blastocyst-stage embryos, but the efficiency is still poor when compared to nonfrozen oocytes [92,94]. First reports of pregnancy were obtained by the transfer of vitrified matured oocytes into the oviducts of inseminated mares [60]. More recently, pregnancy from vitrified oocytes and in vitro embryo culture could be obtained, with pregnancy rates of $17-50 \%$ and resulting in live foals [61,93].

\subsection{Pig}

In pigs, the development of cryopreservation of oocytes has been limited, due principally to the high sensitivity of porcine oocytes to cold stress [56,95]. Although the reason for this is entirely unclear, intracellular lipid content within porcine immature oocytes has been shown to be 2.4-fold higher than in bovine oocytes [96]. Although the removal of cytoplasmic lipids is detrimental to embryo development [97], partial delipidation of porcine oocytes prior to vitrification improved freezing tolerance and embryo development $[12,98]$. Unlike other species, the use of slow freezing has been unsuccessful in terms of survival and embryo development [99]. Because porcine oocytes are very sensitive to cryopreservation, most studies on porcine oocyte cryopreservation used vitrification. Since the first piglets were born after vitrification [56], the efficiency of this technique was much improved in the late 2000s. Modifications of vitrification devices, the type of cryoprotectant and the procedure used were tested, aiming at reducing cryoinjuries and cellular changes of the vitrified-warmed oocytes. Notably, vitrification induces several changes within porcine oocytes, such as in the cytoskeleton [100], mitochondrial abnormalities [101], epigenetic changes [102] and decreased expression level of the Type 1 inositol 1,4,5 trisphosphate receptor [103]. More recently, vitrification of porcine oocytes has been associated with alterations at transcriptomic and proteomic levels $[37,104]$. Similar to other species, both immatureand mature-stage oocytes have been successfully cryopreserved, either by conventional slow freezing or vitrification [105]. In direct comparison, vitrification of immature oocytes results in better cell cytoskeleton rearrangement [106] and embryo development [107]. Additionally, vitrification has been shown to induce parthenogenic activation at a high rate (approximately 50\%) when oocytes are vitrified at the mature stage [108]. Disruption of cellular functions, especially mitochondrial activities, after vitrification leads to increased reactive oxygen species levels and results in cell apoptosis [109-111]. Therefore, the application of antioxidants such as astaxanthin [112] and caspase inhibitor [113] decreased apoptosis and improved the development of vitrified-warmed oocytes.

\subsection{Canines and Felines}

The cryopreservation of canine oocytes has been ignored due to the fact that canine oocytes are poorly resumed to reach metaphase II under in vitro culture conditions. Unlike other species, canine oocytes ovulate at an immature stage. The resumption of meiosis then takes place within the oviduct $[114,115]$. In most cases, matured oocytes would need to be collected from the oviducts, as the immature oocytes require $48-72 \mathrm{~h}$ of maturation time [115]. Clinically, the stage of oocyte maturation is predicted according to ovulation time or progesterone levels $[116,117]$. In in vitro conditions, small numbers of oocytes resumed meiosis and only $15 \%$ reached metaphase II stage. Although puppies have been born using IVF techniques, in vitro embryo production systems in this species have yet to be developed. Only two publications have reported attempts to vitrify canine oocytes $[118,119]$ and only $3.9 \%$ of vitrified-warmed oocytes reached MII stage, comparing unfavorably to $8.2 \%$ MII of nonvitrified control oocytes [118]. The oocytes of nondomestic canines (the endangered Mexican gray wolf, Canis lupus baileyi and blue fox, Alopex lagopus) 
were also vitrified in order to use this technology for species conservation [120,121]. At the time of this report, no data on embryo development or pregnancy resulting from cryopreserved domestic or nondomestic canine oocytes are available.

In comparison with canines, the development of cryopreservation technology in domestic cats has progressed, probably due to oocyte availability and also the well-established in vitro embryo production system [122-127]. Until recently, the development of frozen oocytes in terms of blastocyst development and pregnancy rate has been poor and limited. Full-term development of kittens from vitrified matured oocytes has been reported [54,55]. Pregnancy could also be obtained from vitrified immature oocytes, but reabsorption unfortunately occurred [45]. Until recently, no full-term development of cryopreserved immature oocytes has been reported. It is hypothesized that feline immature oocytes are very sensitive to cryopreservation and also have limited tolerance to aniosmotic conditions [128]. The effects of the meiotic stage on the freezing ability of feline oocytes are still controversial. Indeed, feline oocytes have been successfully cryopreserved using conventional freezing and vitrification at both meiotic stages. Using conventional slow freezing, MII oocytes are significantly more tolerant to slow freezing compared with immature oocytes when cryopreserved slowly with ethylene glycol (cleavage rate $6.8 \%$ vs. 38.7\%) [129]. Similarly, the cleavage rate of vitrified-warmed feline mature oocytes is slightly higher than that of the immature counterparts ( $21 \%$ vs. $4 \%$ ) [130]. Development of the cryopreservation of feline oocytes focused on the use of vitrification yielded $0-10 \%$ blastocyst rates $[54,55,131-134]$. Modifications of the vitrification technique for immature oocytes, such as stepwise ethylene glycol exposure and inhibition of apoptosis with Rock inhibitor improved blastocyst rates (30.2\% and $12.1 \%$, respectively) $[45,135]$.

\subsection{Nonhuman Primates}

In 1996, a study on the cynomolgus monkey or crab-eating macaque (Macaca fascicularis) demonstrated that the F-actin microfilament system in oocytes was modified by glycerol exposure at an ambient temperature [136]. Furthermore, abnormal morphology, represented by irregular shrinkage of oocytes, was observed in germinal vesicle (GV) and metaphase I oocytes after equilibration (room temperature to $0{ }^{\circ} \mathrm{C}$ ) under different concentrations of glycerol (1.0-2.0 M) [136]. For the rhesus monkey (Macaca mulatta), a study revealed that dimethyl sulfoxide and ethylene glycol could effectively diffuse through the oocyte cell membrane. However, the glycerol was less permeated [17]. Additionally, oocyte (immature and mature) membrane integrity was abrupt when exposed to high concentrations of CPA (from 0.1 to $5 \mathrm{~mol} / \mathrm{L}$ ) [17]. A later study in 2005 revealed that rhesus macaque immature oocytes were less susceptible than mature oocytes to injury resulting from a hyperosmotic solution of ethylene glycol during the equilibration phase [137]. Immature oocytes cryopreserved by rapid nonequilibrium cooling suffered less damage compared to slow equilibrium cooling [138]. This was evidenced by the integrity of the microtubules and the intactness of transzonal processes between cumulus cells and oocytes in the rapid-freezing group [138]. Although research studies related to oocyte cryopreservation in nonhuman primates have not in progressed over the last 10 years, nonhuman primate research models were primary keys in understanding the factors involved in oocyte osmotic susceptibility, which could potentially provide a relevant platform for oocyte cryopreservation in humans [14].

\subsection{Humans}

The technology for oocyte cryopreservation in humans is well developed compared with other domestic species because this technology is highly important for clinical prospects. Therefore, chronological development and clinical outcomes are additionally highlighted in this review. The first successful pregnancy outcome using cryopreserved human oocytes was reported in 1986 [18]. The retrieved oocytes were slow-frozen with $1.5 \mathrm{~mol} / \mathrm{L}$ dimethyl sulfoxide. However, a limited number of successful pregnancies by oocyte cryopreservation and conventional IVF have been reported. The growing interest in 
oocyte cryopreservation has been renewed due to the introduction of ICSI technology in the 1990s [5]. This technique could overcome zona pellucida hardening caused by the cryopreservation process, dramatically increasing the clinical pregnancy rate in IVF programs [5]. Since then, several efforts have been made to optimize oocyte cryopreservation protocols, both slow freezing and vitrification, with the ultimate goal of improving pregnancy outcomes and live birth rate $[5,18]$. After the achievements in embryo cryopreservation and ICSI technologies, a renaissance in oocyte cryopreservation was launched in the early 1990s [8]. Human oocytes present a low surface area to volume ratio, resulting in a high susceptibility to intracellular ice formation [139]. Comparative studies in mice and humans during the early 1990s highlighted difficulties in maintaining membrane permeability and the integrity of human oocytes during hyperosmotic solution exposure [140]. Thus, promising freezing protocols were then developed. In 1993, slow freezing using permeable and nonpermeable CPAs (1,2-propanediol (PROH) and sucrose) was performed on mature (MII) oocytes [141]. By this protocol, oocyte survival rate reached $64 \%$ after thawing, and normal spindle and chromosome configurations were observed in $60 \%$ of viable oocytes [141]. Furthermore, cryopreserved oocytes that had undergone normal fertilization achieved development of all two sets of 23 chromosomes [142]. Until the late 1990s to early 2000s, promising cryopreservation protocols progressed aimed at obtaining higher post-thaw survival. Notable results indicated that survival, implantation and pregnancy rates from cryopreserved oocytes were similar to those from post-thawed embryos $[19,143,144]$. These implications revoked research protocols applied on a routine basis and commercial freezing media kits $[19,143,144]$

Another interesting aspect besides oocyte survival rate and quality is genetic alteration during the cryopreservation process. One study in 2012 indicated that slow freezing was associated with the downregulation of genes involved in chromosomal structure maintenance (Kinesin-like protein; KIF2C and KIF3A) and cell cycle regulation (Checkpoint Kinase 2, CHEK2; and Cyclin Dependent Kinase Inhibitor 1B, CDKN1B) that possibly affected oocyte developmental competence [145]. Although pregnancy outcomes are accomplished by oocyte cryopreservation using the slow freezing method, limited numbers of novel research studies have been reported during the last decade. The primary obstacles were the high cost of a programmable freezer and the time-consuming nature of the procedure. Thus, an alternative strategy that could positively influence oocyte survival outcomes and be comparable to the slow freezing technique without using costly equipment was introduced. For human MII oocytes, vitrification was first applied to long-term preservation in 1989 using high concentrations of permeable (DMSO) and nonpermeable (sucrose) CPAs with ultrarapid freezing and thawing rates [146]. Promising results were observed, with more than $80 \%$ intact oocyte morphology [146]. Similar to slow freezing, this cryopreservation procedure was in the development phase for several years $[19,146]$. The first successes in pregnancy outcomes and live births using vitrified oocytes were reported in 1999 [147]. A total of 11 out of of 17 vitrified oocytes (64.7\%), using $40 \%$ EG and $0.6 \mathrm{~mol} / \mathrm{L}$ sucrose, survived. Pronuclear formation was observed in five of them after ICSI. A euploid embryo was transferred to an infertile patient with the final success of a live birth [147]. The initial protocols for oocyte vitrification were emphasized for cryosurvival [148]. The key to successful oocyte survival after vitrification were optimal cooling and warming rates $[148,149]$. In the meantime, another report minimized vitrification solution volume (a droplet of $<0.1 \mu \mathrm{L}$ compared to other protocols using $0.1-0.5 \mu \mathrm{L}$ ) and used a well-designed cryodevice that led to ultrarapid freezing and thawing $\left(40,000{ }^{\circ} \mathrm{C} / \mathrm{min}\right)$ rates [71]. This technique markedly yielded $100 \%$ morphologically intact oocytes and $52 \%$ blastocyst rates [71]. In particular, limited knowledge related to the detrimental effects of CPA toxicity and the vitrification procedure was investigated at the intracellular level [150]. During the early 2000s, simple low-resolution morphological assessment was used, which was not fully adequate to evaluate oocyte quality, fertilization potential or developmental competence [150]. Thus, intracellular oocyte-organelle studies were introduced using several techniques and types of equipment, i.e., polarized light microscopy (PLM), transmission electron microscopy 
(TEM) and epifluorescence or confocal laser scanning microscopy (CLSM) [150]. These technologies potentially provided great detail on the cryoinjuries in each individual vitrified oocyte [150]. For example, TEM micrography could demonstrate vacuolization present in cryopreserved oocyte ooplasm [150]. A lower degree of vacuolization in vitrified oocytes was observed compared with those from a slow freezing procedure [151]. For other organelles, mitochondrial-smooth endoplasmic reticulum (M-SER) aggregation observed by TEM was present in both vitrified-warmed or slow-frozen oocytes [152,153]. Supporting data indicated that an equilibration and freezing solution containing low EG concentration could decrease M-SER aggregation events [153]. The appearance of vacuoles or M-SER aggregation in human MII oocytes can possibly reduce oocyte fertilization and impair embryo development competence by disturbing $\mathrm{Ca}^{2+}$ homeostasis [150].

Not only morphological or ultrastructural oocyte damage but also patterns of genetic change should be of concern during the cryopreservation process. In the genome era, the impact of oocyte vitrification on genetic and epigenetic changes has been comprehensively studied during the last 10 years. For instance, the first study of gene alteration in vitrified human oocytes was published in 2010 [154]. Expression profiles of messenger RNA (mRNA) in single vitrified-thawed oocytes were compared with fresh cohorts [154]. Data revealed that genes encoding proteins essential for oocyte development and specific functions (bone morphogenetic protein 15 (BMP15), growth differentiation factor 9 (GDF9), folliculogenesis-specific basic helix-loop-helix (FIGLA), POU Class 5 homeobox 1 (POU5f1-OCT4) and TATA box binding protein-associated factor 4B (AF4B)) were not altered by vitrification using a commercial vitrification kit [154]. The number of genes studied in 2021 was between fewer than 10 and almost 2000 [155]. Differentially expressed genes were found in vitrified-thawed oocytes compared to fresh MII oocytes (1646 and 341 genes were downregulated and upregulated, respectively) [155]. In cryopreserved oocytes, genes related to oxidative phosphorylation, the lysosome pathway, regulation of lipolysis in adipocytes or the AMPK signaling pathway were upregulated [155]. On the epigenome issue, a recent study in sibling donor oocytes (fresh and vitrified samples) revealed that global DNA methylation (DNA (hydroxy)methylation pattern) did not differ between cohorts [156]. Furthermore, no significant differences were seen in cleavage timing or predictive morphokinetic time intervals between embryos developed from fresh and vitrified oocytes evaluated under time-lapse monitoring [156]. Another point of epigenetic issue, noncoding RNA (miRNA) expression in fresh/vitrified human oocytes was reported in 2019 [157]. At least 22 miRNAs differed between fresh and vitrified oocytes, e.g., miR-134-5p, miR-210-5p, miR-21-3p and miR-465c-5p, which target the PTEN gene (cell apoptosis regulation through oxidative stress pathway) [157]. However, a small sample size was used in these novel genome reports, and correlation between gene expression and other oocyte quality parameters were rarely determined [155]. Hence, other genetic and epigenetic alterations in human oocyte cryopreservation should be further elucidated.

\section{Prospects and Conclusions Regarding Oocyte Cryopreservation}

Advancement in oocyte cryopreservation has progressed rapidly for decades with satisfactory outcomes, but the study of cryobiology aimed at improving outcomes for the cryopreserved oocyte is still challenging. However, development and success rates in terms of survival and developmental competence are generally poor when compared to noncryopreserved oocytes. Additionally, the degree of oocyte susceptibility to cold stress and cryodamage is highly dependent upon species and the freezing technology used. Animal models are used to investigate the principle and effectiveness of freezing protocols, which later can be used efficiently with other reproductive technologies. The purposes of oocyte cryopreservation are globally similar between animals and humans; however, the ultimate aim in animals is to preserve oocytes for subsequent use and for "long-term" genome resource banking in wild species [158]. In humans, oocyte cryopreservation is clinically adapted as a tool for preserving fertility in cases of its premature loss, such as in women who need gonadotoxic chemotherapy for cancer treatment [159-162]. Indeed, 
oocytes differ from other cell types such as somatic cells and sperm cells as they are larger, have a low surface area to volume ratio, and also low membrane permeability to water and CPA, all of which make oocytes susceptible to damage during cryopreservation [24]. As a result, several types of cryoinjury, such as disorganization of microtubules and chromatin configuration, zona pellucida hardening, apoptosis and genetic and epigenetic alterations will inevitably occur when cryopreservation is carried out. It becomes clear that the cryopreservation of oocytes in animals remains at the experimental stage, as the outcomes in terms of live offspring are very limited. Of course, the ultimate goal in the study of oocyte cryopreservation would be to determine the factors that influence cryoinjury and to minimize their effects on the biological functions of the cryopreserved oocytes. Indeed, empirical studies on animals and variations in the protocols used have led to difficulties in comparing results among laboratories. However, the development of freezing techniques, in particular vitrification, is the most noticeable revolution in cryopreservation. This is likely due to the fact that vitrification can avoid the lethal ice formation seen in conventional slow freezing [19]. In addition, vitrification is less time-consuming and more cost-effective. In experimental phases, most researchers attempt to modify cryodevices to increase cooling and warming rates and also to modify different types of CPAs. However, the variations in oocyte structures and physiology among animal species cause difficulties in formulating a consensus on freezing techniques for all species. This is not the case for humans, as a range of devices and reagents is mostly commercially available, and comparative studies between laboratories can be performed much more easily than for animals. A search for new technologies is also required to identify the mechanisms of cryoinjury by using novel molecular tools such as gene sequencing and proteomic analysis. Several technologies are foreseen to be used in the future, such as microfluidics [163-165]. Future prospective issues of fertility preservation can also be examined via the development of cryopreservation/transplantation technologies for oocytes growing in ovarian tissue [161], and also for genetic modifications using novel genome editing tools. Material sciences using three-dimensional (3D) structures (e.g., tissue decellularization scaffolds or fibrin/thrombin structures) can be used to protect oocytes against cryoinjury and promote their development post cryopreservation. Lastly, cross contamination with pathogens in liquid nitrogen is also important for safety reasons, especially during the coronavirus 2019 (COVID-19) pandemic. The presence of angiotensin-converting enzyme (ACE 1-7) has been identified in human ovarian and granulosa cells [166,167]. Thus, there is a major concern on the risk of SARS-CoV-2 contamination in ART procedures, including oocyte retrieval and cryopreservation [166]. Although viral RNA was not detectable in the oocytes and follicular fluid of SARS-CoV-2-positive patients [168,169], larger case studies in all IVF procedures with careful interpretation should be elucidated [169]. For this hygiene security reason, it would be preferable to develop different types of cryodevices using

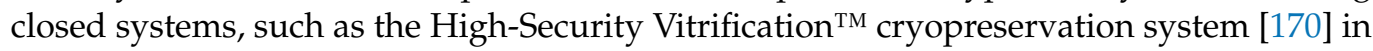
order to avoid cross contamination from liquid nitrogen.

Author Contributions: T.T. and P.T. equally contribute to the conceptualization, resources, data curation, original draft preparation and editing. All authors have read and agreed to the published version of the manuscript.

Funding: This research was funded by the Thailand Research Fund (RSA6180053) and MSCA Rise (EU H2020 Drynet), GA 734434.

Institutional Review Board Statement: Not applicable.

Informed Consent Statement: Not applicable.

Data Availability Statement: Not applicable.

Acknowledgments: This review was supported by the Veterinary Clinical Stem Cells and Bioengineering Research Unit, Chulalongkorn University.

Conflicts of Interest: The author declare no conflict of interest. 


\section{References}

1. Parkening, T.A.; Tsunoda, Y.; Chang, M.C. Effects of various low temperatures, cryoprotective agents and cooling rates on the survival, fertilizability and development of frozen-thawed mouse eggs. J. Exp. Zool. 1976, 197, 369-374. [CrossRef]

2. Whittingham, D.G. Fertilization In Vitro and development to term of unfertilized mouse oocytes previously stored at -196 degrees C. J. Reprod. Fertil. 1977, 49, 89-94. [CrossRef]

3. Dinnyés, A.; Dai, Y.; Jiang, S.; Yang, X. High developmental rates of vitrified bovine oocytes following parthenogenetic activation, In Vitro fertilization, and somatic cell nuclear transfer. Biol. Reprod. 2000, 63, 513-518. [CrossRef] [PubMed]

4. Smith, G.D.; Motta, E.E.; Serafini, P. Theoretical and experimental basis of oocyte vitrification. Reprod. Biomed. Online 2011, 23, 298-306. [CrossRef]

5. Chian, R.-C.; Wang, Y.; Li, Y.-R. Oocyte vitrification: Advances, progress and future goals. J. Assist. Reprod. Genet. 2014, 31, 411-420. [CrossRef] [PubMed]

6. De Santis, L.; Coticchio, G. Reprint of: Theoretical and experimental basis of slow freezing. Reprod. Biomed. Online 2011, 23, 290-297. [CrossRef]

7. Rienzi, L.; Gracia, C.; Maggiulli, R.; LaBarbera, A.R.; Kaser, D.J.; Ubaldi, F.M.; Vanderpoel, S.; Racowsky, C. Oocyte, embryo and blastocyst cryopreservation in ART: Systematic review and meta-analysis comparing slow-freezing versus vitrification to produce evidence for the development of global guidance. Hum. Reprod. Update 2017, 23, 139-155. [CrossRef] [PubMed]

8. Boldt, J. Current results with slow freezing and vitrification of the human oocyte. Reprod. Biomed. Online 2011, $23,314-322$. [CrossRef]

9. Rall, W.F.; Fahy, G.M. Ice-free cryopreservation of mouse embryos at- 196 C by vitrification. Nature 1985, 313, 573-575. [CrossRef]

10. Arav, A.; Natan, Y. Vitrification of oocytes: From basic science to clinical application. Adv. Exp. Med. Biol. 2013, 761, 69-83. [CrossRef]

11. Cil, A.P.; Seli, E. Current trends and progress in clinical applications of oocyte cryopreservation. Curr. Opin. Obs. Gynecol. 2013, 25, 247-254. [CrossRef]

12. Ogawa, B.; Ueno, S.; Nakayama, N.; Matsunari, H.; Nakano, K.; Fujiwara, T.; Ikezawa, Y.; Nagashima, H. Developmental ability of porcine In Vitro matured oocytes at the meiosis II stage after vitrification. J. Reprod. Dev. 2010, 56, 356-361. [CrossRef]

13. Park, K.E.; Kwon, I.K.; Han, M.S.; Niwa, K. Effects of partial removal of cytoplasmic lipid on survival of vitrified germinal vesicle stage pig oocytes. J. Reprod. Dev. 2005, 51, 151-160. [CrossRef]

14. Wolf, D. The non-human primate oocyte and embryo as a model for women, or is it vice versa? Theriogenology 2008, 69, 31-36. [CrossRef] [PubMed]

15. DeMayo, F.J.; Rawlins, R.G.; Dukelow, W.R. Xenogenous and In Vitro fertilization of frozen/thawed primate oocytes and blastomere separation of embryos. Fertil. Steril. 1985, 43, 295-300. [CrossRef]

16. Lanzendorf, S.; Holmgren, W.; Schaffer, N.; Hatasaka, H.; Wentz, A.; Jeyendran, R. In Vitro fertilization and gamete micromanipulation in the lowland gorilla. J. Assist. Reprod. Genet. 1992, 9, 358-364. [CrossRef] [PubMed]

17. Songsasen, N.; Ratterree, M.; VandeVoort, C.; Pegg, D.; Leibo, S. Permeability characteristics and osmotic sensitivity of rhesus monkey (Macaca mulatta) oocytes. Hum. Reprod. 2002, 17, 1875-1884. [CrossRef] [PubMed]

18. Chen, C. Pregnancy after human oocyte cryopreservation. Lancet 1986, 327, 884-886. [CrossRef]

19. Koutlaki, N.; Schoepper, B.; Maroulis, G.; Diedrich, K.; Al-Hasani, S. Human oocyte cryopreservation: Past, present and future. Reprod. BioMed. Online 2006, 13, 427-436. [CrossRef]

20. Ethics, E.T.F.O.; Law, I.; Dondorp, W.; de Wert, G.; Pennings, G.; Shenfield, F.; Devroey, P.; Tarlatzis, B.; Barri, P.; Diedrich, K. Oocyte cryopreservation for age-related fertility loss. Hum. Reprod. 2012, 27, 1231-1237.

21. Cobo, A.; Meseguer, M.; Remohí, J.; Pellicer, A. Use of cryo-banked oocytes in an ovum donation programme: A prospective, randomized, controlled, clinical trial. Hum. Reprod. 2010, 25, 2239-2246. [CrossRef]

22. Platts, S.; Trigg, B.; Bracewell-Milnes, T.; Jones, B.P.; Saso, S.; Parikh, J.; Nicopoullos, J.; Almeida, P.; Norman-Taylor, J.; Nikolaou, D. Exploring women's attitudes, knowledge, and intentions to use oocyte freezing for non-medical reasons: A systematic review. Acta Obstet. Gynecol. Scand. 2021, 100, 383-393. [CrossRef] [PubMed]

23. Levi-Setti, P.E.; Patrizio, P.; Scaravelli, G. Evolution of human oocyte cryopreservation: Slow freezing versus vitrification. Curr. Opin. Endocrinol. Diabetes Obes. 2016, 23, 445-450. [CrossRef] [PubMed]

24. Leibo, S.P. Water permeability and its activation energy of fertilized and unfertilized mouse ova. J. Membr. Biol. 1980, 53, 179-188. [CrossRef] [PubMed]

25. Ashwood-Smith, M.J.; Morris, G.W.; Fowler, R.; Appleton, T.C.; Ashorn, R. Physical factors are involved in the destruction of embryos and oocytes during freezing and thawing procedures. Hum. Reprod. 1988, 3, 795-802. [CrossRef] [PubMed]

26. Saunders, K.M.; Parks, J.E. Effects of cryopreservation procedures on the cytology and fertilization rate of In Vitro-matured bovine oocytes. Biol. Reprod. 1999, 61, 178-187. [CrossRef]

27. Shaw, J.M.; Oranratnachai, A.; Trounson, A.O. Fundamental cryobiology of mammalian oocytes and ovarian tissue. Theriogenology 2000, 53, 59-72. [CrossRef]

28. Leibo, S.P.; McGrath, J.J.; Cravalho, E.G. Microscopic observation of intracellular ice formation in unfertilized mouse ova as a function of cooling rate. Cryobiology 1978, 15, 257-271. [CrossRef]

29. Glenister, P.H.; Wood, M.J.; Kirby, C.; Whittingham, D.G. Incidence of chromosome anomalies in first-cleavage mouse embryos obtained from frozen-thawed oocytes fertilized In Vitro. Gamete Res. 1987, 16, 205-216. [CrossRef] 
30. Arav, A.; Shehu, D.; Mattioli, M. Osmotic and cytotoxic study of vitrification of immature bovine oocytes. J. Reprod. Fertil. 1993, 99, 353-358. [CrossRef]

31. Agca, Y.; Liu, J.; Rutledge, J.J.; Critser, E.S.; Critser, J.K. Effect of osmotic stress on the developmental competence of germinal vesicle and metaphase II stage bovine cumulus oocyte complexes and its relevance to cryopreservation. Mol. Reprod. Dev. 2000, 55, 212-219. [CrossRef]

32. Tharasanit, T.; Colenbrander, B.; Stout, T.A. Effect of maturation stage at cryopreservation on post-thaw cytoskeleton quality and fertilizability of equine oocytes. Mol. Reprod. Dev. 2006, 73, 627-637. [CrossRef] [PubMed]

33. Carroll, J.; Depypere, H.; Matthews, C.D. Freeze-thaw-induced changes of the zona pellucida explains decreased rates of fertilization in frozen-thawed mouse oocytes. J. Reprod. Fertil. 1990, 90, 547-553. [CrossRef]

34. Wang, N.; Li, C.Y.; Zhu, H.B.; Hao, H.S.; Wang, H.Y.; Yan, C.L.; Zhao, S.J.; Du, W.H.; Wang, D.; Liu, Y.; et al. Effect of vitrification on the mRNA transcriptome of bovine oocytes. Reprod. Domest. Anim. 2017, 52, 531-541. [CrossRef] [PubMed]

35. Ma, Y.; Pan, B.; Yang, H.; Qazi, I.H.; Wu, Z.; Zeng, C.; Zhang, M.; Meng, Q.; Zhou, G. Expression of CD9 and CD81 in bovine germinal vesicle oocytes after vitrification followed by In Vitro maturation. Cryobiology 2018, 81, 206-209. [CrossRef] [PubMed]

36. Eroglu, B.; Szurek, E.A.; Schall, P.; Latham, K.E.; Eroglu, A. Probing lasting cryoinjuries to oocyte-embryo transcriptome. PLoS ONE 2020, 15, e0231108. [CrossRef]

37. Jia, B.; Xiang, D.; Fu, X.; Shao, Q.; Hong, Q.; Quan, G.; Wu, G. Proteomic changes of porcine oocytes after vitrification and subsequent in vitro maturation: A Tandem Mass Tag-based quantitative analysis. Front. Cell Dev. Biol. 2020, 8, 614577. [CrossRef] [PubMed]

38. Elliott, G.D.; Wang, S.; Fuller, B.J. Cryoprotectants: A review of the actions and applications of cryoprotective solutes that modulate cell recovery from ultra-low temperatures. Cryobiology 2017, 76, 74-91. [CrossRef]

39. Whaley, D.; Damyar, K.; Witek, R.P.; Mendoza, A.; Alexander, M.; Lakey, J.R. Cryopreservation: An Overview of Principles and Cell-Specific Considerations. Cell Transpl. 2021, 30, 963689721999617. [CrossRef]

40. Mazur, P. Cryobiology: The freezing of biological systems. Science 1970, 168, 939-949. [CrossRef]

41. Fuller, B.J. Cryoprotectants: The essential antifreezes to protect life in the frozen state. CryoLetters 2004, 25, 375-388. [PubMed]

42. Eroglu, A. Cryopreservation of mammalian oocytes by using sugars: Intra- and extracellular raffinose with small amounts of dimethylsulfoxide yields high cryosurvival, fertilization, and development rates. Cryobiology 2010, 60, S54-S59. [CrossRef] [PubMed]

43. Seet, V.Y.; Al-Samerria, S.; Wong, J.; Stanger, J.; Yovich, J.L.; Almahbobi, G. Optimising vitrification of human oocytes using multiple cryoprotectants and morphological and functional assessment. Reprod. Fertil. Dev. 2013, 25, 918-926. [CrossRef] [PubMed]

44. Kohaya, N.; Fujiwara, K.; Ito, J.; Kashiwazaki, N. High developmental rates of mouse oocytes cryopreserved by an optimized vitrification protocol: The effects of cryoprotectants, calcium and cumulus cells. J. Reprod. Dev. 2011, 57, 675-680. [CrossRef] [PubMed]

45. Tharasanit, T.; Manee-In, S.; Buarpung, S.; Chatdarong, K.; Lohachit, C.; Techakumphu, M. Successful pregnancy following transfer of feline embryos derived from vitrified immature cat oocytes using "stepwise" cryoprotectant exposure technique. Theriogenology 2011, 76, 1442-1449. [CrossRef] [PubMed]

46. Vajta, G.; Nagy, Z.P.; Cobo, A.; Conceicao, J.; Yovich, J. Vitrification in assisted reproduction: Myths, mistakes, disbeliefs and confusion. Reprod. Biomed. Online 2009, 19, 1-7. [CrossRef]

47. Woods, E.J.; Benson, J.D.; Agca, Y.; Critser, J.K. Fundamental cryobiology of reproductive cells and tissues. Cryobiology 2004, 48, 146-156. [CrossRef]

48. Vajta, G.; Holm, P.; Kuwayama, M.; Booth, P.J.; Jacobsen, H.; Greve, T.; Callesen, H. Open Pulled Straw (OPS) vitrification: A new way to reduce cryoinjuries of bovine ova and embryos. Mol. Reprod. Dev. 1998, 51, 53-58. [CrossRef]

49. Lane, M.; Bavister, B.D.; Lyons, E.A.; Forest, K.T. Containerless vitrification of mammalian oocytes and embryos. Nat. Biotechnol. 1999, 17, 1234-1236. [CrossRef]

50. Martino, A.; Songsasen, N.; Leibo, S.P. Development into blastocysts of bovine oocytes cryopreserved by ultra-rapid cooling. Biol. Reprod. 1996, 54, 1059-1069. [CrossRef]

51. Kuwayama, M. Highly efficient vitrification for cryopreservation of human oocytes and embryos: The Cryotop method. Theriogenology 2007, 67, 73-80. [CrossRef]

52. Nakagata, N.; Takeo, T.; Fukumoto, K.; Kondo, T.; Haruguchi, Y.; Takeshita, Y.; Nakamuta, Y.; Matsunaga, H.; Tsuchiyama, S.; Ishizuka, Y.; et al. Applications of cryopreserved unfertilized mouse oocytes for In Vitro fertilization. Cryobiology 2013, 67, 188-192. [CrossRef] [PubMed]

53. Mochida, K. Development of assisted reproductive technologies in small animal species for their efficient preservation and production. J. Reprod. Dev. 2020, 66, 299-306. [CrossRef]

54. Pope, C.E.; Gómez, M.C.; Kagawa, N.; Kuwayama, M.; Leibo, S.P.; Dresser, B.L. In Vivo survival of domestic cat oocytes after vitrification, intracytoplasmic sperm injection and embryo transfer. Theriogenology 2012, 77, 531-538. [CrossRef] [PubMed]

55. Galiguis, J.; Gómez, M.C.; Leibo, S.P.; Pope, C.E. Birth of a domestic cat kitten produced by vitrification of lipid polarized In Vitro matured oocytes. Cryobiology 2014, 68, 459-466. [CrossRef] [PubMed] 
56. Somfai, T.; Yoshioka, K.; Tanihara, F.; Kaneko, H.; Noguchi, J.; Kashiwazaki, N.; Nagai, T.; Kikuchi, K. Generation of live piglets from cryopreserved oocytes for the first time using a defined system for In Vitro embryo production. PLoS ONE 2014, 9, e97731. [CrossRef]

57. Fuku, E.; Kojima, T.; Shioya, Y.; Marcus, G.J.; Downey, B.R. In Vitro fertilization and development of frozen-thawed bovine oocytes. Cryobiology 1992, 29, 485-492. [CrossRef]

58. Otoi, T.; Yamamoto, K.; Koyama, N.; Suzuki, T. In Vitro fertilization and development of immature and mature bovine oocytes cryopreserved by ethylene glycol with sucrose. Cryobiology 1995, 32, 455-460. [CrossRef]

59. Suzuki, T.; Boediono, A.; Takagi, M.; Saha, S.; Sumantri, C. Fertilization and development of frozen-thawed germinal vesicle bovine oocytes by a one-step dilution method In Vitro. Cryobiology 1996, 33, 515-524. [CrossRef]

60. Maclellan, L.J.; Carnevale, E.M.; Coutinho da Silva, M.A.; Scoggin, C.F.; Bruemmer, J.E.; Squires, E.L. Pregnancies from vitrified equine oocytes collected from super-stimulated and non-stimulated mares. Theriogenology 2002, 58, 911-919. [CrossRef]

61. Ortiz-Escribano, N.; Bogado Pascottini, O.; Woelders, H.; Vandenberghe, L.; De Schauwer, C.; Govaere, J.; Van den Abbeel, E.; Vullers, T.; Ververs, C.; Roels, K.; et al. An improved vitrification protocol for equine immature oocytes, resulting in a first live foal. Equine Vet. J. 2018, 50, 391-397. [CrossRef] [PubMed]

62. Hamano, S.; Koikeda, A.; Kuwayama, M.; Nagai, T. Full-term development of In Vitro-matured, vitrified and fertilized bovine oocytes. Theriogenology 1992, 38, 1085-1090. [CrossRef]

63. Martino, A.; Pollard, J.W.; Leibo, S.P. Effect of chilling bovine oocytes on their developmental competence. Mol. Reprod. Dev. 1996, 45, 503-512. [CrossRef]

64. Kubota, C.; Yang, X.; Dinnyes, A.; Todoroki, J.; Yamakuchi, H.; Mizoshita, K.; Inohae, S.; Tabara, N. In Vitro and in vivo survival of frozen-thawed bovine oocytes after IVF, nuclear transfer, and parthenogenetic activation. Mol. Reprod. Dev. 1998, 51, 281-286. [CrossRef]

65. Vieira, A.D.; Forell, F.; Feltrin, C.; Rodrigues, J.L. Calves born after direct transfer of vitrified bovine In Vitro-produced blastocysts derived from vitrified immature oocytes. Reprod. Domest. Anim. 2008, 43, 314-318. [CrossRef]

66. Mavrides, A.; Morroll, D. Cryopreservation of bovine oocytes: Is cryoloop vitrification the future to preserving the female gamete? Reprod. Nutr. Dev. 2002, 42, 73-80. [CrossRef] [PubMed]

67. Chian, R.C.; Kuwayama, M.; Tan, L.; Tan, J.; Kato, O.; Nagai, T. High survival rate of bovine oocytes matured In Vitro following vitrification. J. Reprod. Dev. 2004, 50, 685-696. [CrossRef] [PubMed]

68. Chinen, S.; Yamanaka, T.; Nakayama, K.; Watanabe, H.; Akiyama, Y.; Hirabayashi, M.; Hochi, S. Nylon mesh cryodevice for bovine mature oocytes, easily removable excess vitrification solution. Cryobiology 2019, 90, 96-99. [CrossRef] [PubMed]

69. Nakayama, K.; Chinen, S.; Teshima, J.; Tamada, Y.; Hirabayashi, M.; Hochi, S. Silk fibroin sheet multilayer suitable for vitrification of In Vitro-matured bovine oocytes. Theriogenology 2020, 145, 109-114. [CrossRef]

70. Papis, K.; Shimizu, M.; Izaike, Y. Factors affecting the survivability of bovine oocytes vitrified in droplets. Theriogenology 2000, 54, 651-658. [CrossRef]

71. Kuwayama, M.; Vajta, G.; Ieda, S.; Kato, O. Comparison of open and closed methods for vitrification of human embryos and the elimination of potential contamination. Reprod. Biomed. Online 2005, 11, 608-614. [CrossRef]

72. Bhat, M.H.; Sharma, V.; Khan, F.A.; Naykoo, N.A.; Yaqoob, S.H.; Ruby; Khan, H.M.; Fazili, M.R.; Ganai, N.A.; Shah, R.A. Comparison of slow freezing and vitrification on ovine immature oocytes. CryoLetters 2014, 35, 77-82. [PubMed]

73. Le Gal, F. In vitro maturation and fertilization of goat oocytes frozen at the germinal vesicle stage. Theriogenology 1996, 45, 1177-1185. [CrossRef]

74. Purohit, G.N.; Meena, H.; Solanki, K. Effects of Vitrification on Immature and In Vitro Matured, Denuded and Cumulus Compact Goat Oocytes and Their Subsequent Fertilization. J. Reprod. Infertil. 2012, 13, 53-59. [PubMed]

75. Quan, G.B.; Wu, G.Q.; Wang, Y.J.; Ma, Y.; Lv, C.R.; Hong, Q.H. Meiotic maturation and developmental capability of ovine oocytes at germinal vesicle stage following vitrification using different cryodevices. Cryobiology 2016, 72, 33-40. [CrossRef]

76. Moawad, A.R.; Zhu, J.; Choi, I.; Amarnath, D.; Chen, W.; Campbell, K.H. Production of good-quality blastocyst embryos following IVF of ovine oocytes vitrified at the germinal vesicle stage using a cryoloop. Reprod. Fertil. Dev. 2013, 25, 1204-1215. [CrossRef]

77. Hosseini, S.M.; Asgari, V.; Ostadhosseini, S.; Hajian, M.; Ghanaei, H.R.; Nasr-Esfahani, M.H. Developmental competence of ovine oocytes after vitrification: Differential effects of vitrification steps, embryo production methods, and parental origin of pronuclei. Theriogenology 2015, 83, 366-376. [CrossRef]

78. Succu, S.; Berlinguer, F.; Leoni, G.G.; Bebbere, D.; Satta, V.; Marco-Jimenez, F.; Pasciu, V.; Naitana, S. Calcium concentration in vitrification medium affects the developmental competence of In Vitro matured ovine oocytes. Theriogenology 2011, 75, 715-721. [CrossRef]

79. Davoodian, N.; Kadivar, A.; Ahmadi, E.; Nazari, H.; Mehrban, H. Quercetin effect on the efficiency of ovine oocyte vitrification at GV stage. Theriogenology 2021, 174, 53-59. [CrossRef]

80. Moawad, A.R.; Choi, I.; Zhu, J.; El-Wishy, A.B.A.; Amarnath, D.; Chen, W.; Campbell, K.H.S. Caffeine and oocyte vitrification: Sheep as an animal model. Int. J. Vet. Sci. Med. 2018, 6, S41-S48. [CrossRef]

81. Succu, S.; Leoni, G.G.; Bebbere, D.; Berlinguer, F.; Mossa, F.; Bogliolo, L.; Madeddu, M.; Ledda, S.; Naitana, S. Vitrification devices affect structural and molecular status of In Vitro matured ovine oocytes. Mol. Reprod. Dev. 2007, 74, 1337-1344. [CrossRef] [PubMed] 
82. Galli, C.; Crotti, G.; Notari, C.; Turini, P.; Duchi, R.; Lazzari, G. Embryo production by ovum pick up from live donors. Theriogenology 2001, 55, 1341-1357. [CrossRef]

83. Lazzari, G.; Colleoni, S.; Crotti, G.; Turini, P.; Fiorini, G.; Barandalla, M.; Landriscina, L.; Dolci, G.; Benedetti, M.; Duchi, R.; et al. Laboratory Production of Equine Embryos. J. Equine Vet. Sci. 2020, 89, 103097. [CrossRef] [PubMed]

84. Fortune, J.E.; Kimmich, T.L. Purified pig FSH increases the rate of double ovulation in mares. Equine Vet. J. 1993, 15, 95-98. [CrossRef]

85. Hawley, L.R.; Enders, A.C.; Hinrichs, K. Comparison of Equine and Bovine Oocyte-Cumulus Morphology within the Ovarian Follicle1. Biol. Reprod. 2018, 52, 243-252. [CrossRef]

86. Dell'Aquila, M.E.; Cho, Y.S.; Minoia, P.; Traina, V.; Lacalandra, G.M.; Maritato, F. Effects of follicular fluid supplementation of in-vitro maturation medium on the fertilization and development of equine oocytes after in-vitro fertilization or intracytoplasmic sperm injection. Hum. Reprod. 1997, 12, 2766-2772. [CrossRef]

87. Hochi, S.; Kozawa, M.; Fujimoto, T.; Hondo, E.; Yamada, J.; Oguri, N. In vitro maturation and transmission electron microscopic observation of horse oocytes after vitrification. Cryobiology 1996, 33, 300-310. [CrossRef]

88. Ducheyne, K.D.; Rizzo, M.; Daels, P.F.; Stout, T.A.E.; de Ruijter-Villani, M. Vitrifying immature equine oocytes impairs their ability to correctly align the chromosomes on the MII spindle. Reprod. Fertil. Dev. 2019, 31, 1330-1338. [CrossRef]

89. Hurtt, A.E.; Landim-Alvarenga, F.; Seidel, G.E., Jr.; Squires, E.L. Vitrification of immature and mature equine and bovine oocytes in an ethylene glycol, ficoll and sucrose solution using open-pulled straws. Theriogenology 2000, 54, 119-128. [CrossRef]

90. Angel, D.; Canesin, H.S.; Brom-de-Luna, J.G.; Morado, S.; Dalvit, G.; Gomez, D.; Posada, N.; Pascottini, O.B.; Urrego, R.; Hinrichs, K.; et al. Embryo development after vitrification of immature and In Vitro-matured equine oocytes. Cryobiology 2020, 92, 251-254. [CrossRef]

91. Canesin, H.S.; Brom-de-Luna, J.G.; Choi, Y.H.; Pereira, A.M.; Macedo, G.G.; Hinrichs, K. Vitrification of germinal-vesicle stage equine oocytes: Effect of cryoprotectant exposure time on in-vitro embryo production. Cryobiology 2018, 81, 185-191. [CrossRef]

92. Agnieszka, N.; Joanna, K.; Wojciech, W.; Adam, O. In vitro maturation of equine oocytes followed by two vitrification protocols and subjected to either intracytoplasmic sperm injection (ICSI) or parthenogenic activation. Theriogenology 2021, 162, 42-48. [CrossRef] [PubMed]

93. Clérico, G.; Taminelli, G.; Veronesi, J.C.; Polola, J.; Pagura, N.; Pinto, C.; Sansinena, M. Mitochondrial function, blastocyst development and live foals born after ICSI of immature vitrified/warmed equine oocytes matured with or without melatonin. Theriogenology 2021, 160, 40-49. [CrossRef] [PubMed]

94. Tharasanit, T.; Colleoni, S.; Lazzari, G.; Colenbrander, B.; Galli, C.; Stout, T.A. Effect of cumulus morphology and maturation stage on the cryopreservability of equine oocytes. Reproduction 2006, 132, 759-769. [CrossRef] [PubMed]

95. Appeltant, R.; Somfai, T.; Santos, E.C.S.; Dang-Nguyen, T.Q.; Nagai, T.; Kikuchi, K. Effects of vitrification of cumulus-enclosed porcine oocytes at the germinal vesicle stage on cumulus expansion, nuclear progression and cytoplasmic maturation. Reprod. Fertil. Dev. 2017, 29, 2419-2429. [CrossRef] [PubMed]

96. Genicot, G.; Leroy, J.L.; Soom, A.V.; Donnay, I. The use of a fluorescent dye, Nile red, to evaluate the lipid content of single mammalian oocytes. Theriogenology 2005, 63, 1181-1194. [CrossRef]

97. Ren, L.; Fu, B.; Ma, H.; Liu, D. Effects of mechanical delipation in porcine oocytes on mitochondrial distribution, ROS activity and viability after vitrification. CryoLetters 2015, 36, 30-36.

98. Hara, K.; Abe, Y.; Kumada, N.; Aono, N.; Kobayashi, J.; Matsumoto, H.; Sasada, H.; Sato, E. Extrusion and removal of lipid from the cytoplasm of porcine oocytes at the germinal vesicle stage: Centrifugation under hypertonic conditions influences vitrification. Cryobiology 2005, 50, 216-222. [CrossRef]

99. Yang, C.Y.; Chen, M.C.; Lee, P.T.; Lin, T.T. Cryopreservation of germinal vesicle stage porcine oocytes based on intracellular ice formation assessment. CryoLetters 2012, 33, 349-362.

100. López, A.; Ducolomb, Y.; Casas, E.; Retana-Márquez, S.; Betancourt, M.; Casillas, F. Effects of Porcine Immature Oocyte Vitrification on Actin Microfilament Distribution and Chromatin Integrity During Early Embryo Development In Vitro. Front. Cell Dev. Biol. 2021, 9, 636765. [CrossRef]

101. Dai, J.; Wu, C.; Muneri, C.W.; Niu, Y.; Zhang, S.; Rui, R.; Zhang, D. Changes in mitochondrial function in porcine vitrified MII-stage oocytes and their impacts on apoptosis and developmental ability. Cryobiology 2015, 71, 291-298. [CrossRef]

102. Spinaci, M.; Vallorani, C.; Bucci, D.; Tamanini, C.; Porcu, E.; Galeati, G. Vitrification of pig oocytes induces changes in histone H4 acetylation and histone $\mathrm{H} 3$ lysine 9 methylation (H3K9). Vet. Res. Commun. 2012, 36, 165-171. [CrossRef]

103. Hirose, M.; Kamoshita, M.; Fujiwara, K.; Kato, T.; Nakamura, A.; Wojcikiewicz, R.J.; Parys, J.B.; Ito, J.; Kashiwazaki, N. Vitrification procedure decreases inositol 1,4,5-trisphophate receptor expression, resulting in low fertility of pig oocytes. Anim. Sci. J. 2013, 84, 693-701. [CrossRef]

104. Jia, B.Y.; Xiang, D.C.; Quan, G.B.; Zhang, B.; Shao, Q.Y.; Hong, Q.H.; Wu, G.Q. Transcriptome analysis of porcine immature oocytes and surrounding cumulus cells after vitrification and in vitro maturation. Theriogenology 2019, 134, 90-97. [CrossRef] [PubMed]

105. Somfai, T.; Kikuchi, K.; Nagai, T. Factors affecting cryopreservation of porcine oocytes. J. Reprod. Dev. 2012, 58, 17-24. [CrossRef] [PubMed] 
106. Egerszegi, I.; Somfai, T.; Nakai, M.; Tanihara, F.; Noguchi, J.; Kaneko, H.; Nagai, T.; Rátky, J.; Kikuchi, K. Comparison of cytoskeletal integrity, fertilization and developmental competence of oocytes vitrified before or after In Vitro maturation in a porcine model. Cryobiology 2013, 67, 287-292. [CrossRef] [PubMed]

107. Wu, G.; Jia, B.; Mo, X.; Liu, C.; Fu, X.; Zhu, S.; Hou, Y. Nuclear maturation and embryo development of porcine oocytes vitrified by cryotop: Effect of different stages of In Vitro maturation. Cryobiology 2013, 67, 95-101. [CrossRef]

108. Somfai, T.; Ozawa, M.; Noguchi, J.; Kaneko, H.; Kuriani Karja, N.W.; Farhudin, M.; Dinnyés, A.; Nagai, T.; Kikuchi, K. Developmental competence of In Vitro-fertilized porcine oocytes after In Vitro maturation and solid surface vitrification: Effect of cryopreservation on oocyte antioxidative system and cell cycle stage. Cryobiology 2007, 55, 115-126. [CrossRef]

109. Mateo-Otero, Y.; Yeste, M.; Damato, A.; Giaretta, E. Cryopreservation and oxidative stress in porcine oocytes. Res. Vet. Sci. 2021, 135, 20-26. [CrossRef]

110. Dai, J.J.; Niu, Y.F.; Wu, C.F.; Zhang, S.H.; Zhang, D.F. Both death receptor and mitochondria mediated apoptotic pathways participated the occurrence of apoptosis in porcine vitrified mii stage oocytes. CryoLetters 2016, 37, 129-136.

111. Vallorani, C.; Spinaci, M.; Bucci, D.; Porcu, E.; Tamanini, C.; Galeati, G. Pig oocyte vitrification by Cryotop method and the activation of the apoptotic cascade. Anim. Reprod. Sci. 2012, 135, 68-74. [CrossRef]

112. Xiang, D.C.; Jia, B.Y.; Fu, X.W.; Guo, J.X.; Hong, Q.H.; Quan, G.B.; Wu, G.Q. Role of astaxanthin as an efficient antioxidant on the in vitro maturation and vitrification of porcine oocytes. Theriogenology 2021, 167, 13-23. [CrossRef]

113. Niu, Y.; Dai, J.; Chen, Y.; Wu, C.; Zhang, S.; Zhang, D. Positive effect of apoptotic inhibitor Z-vad-fmk on vitrified-thawed porcine mii stage oocytes. CryoLetters 2016, 37, 188-195.

114. Reynaud, K.; Fontbonne, A.; Marseloo, N.; Viaris de Lesegno, C.; Saint-Dizier, M.; Chastant-Maillard, S. In vivo canine oocyte maturation, fertilization and early embryogenesis: A review. Theriogenology 2006, 66, 1685-1693. [CrossRef] [PubMed]

115. Songsasen, N.; Wildt, D.E. Oocyte biology and challenges in developing In Vitro maturation systems in the domestic dog. Anim. Reprod. Sci. 2007, 98, 2-22. [CrossRef]

116. Kim, J.J.; Park, K.B.; Choi, E.J.; Hyun, S.H.; Kim, N.H.; Jeong, Y.W.; Hwang, W.S. Relationship between time post-ovulation and progesterone on oocyte maturation and pregnancy in canine cloning. Anim. Reprod. Sci. 2017, 185, 75-82. [CrossRef]

117. Reynaud, K.; Saint-Dizier, M.; Tahir, M.Z.; Havard, T.; Harichaux, G.; Labas, V.; Thoumire, S.; Fontbonne, A.; Grimard, B.; Chastant-Maillard, S. Progesterone plays a critical role in canine oocyte maturation and fertilization. Biol. Reprod. 2015, 93, 87. [CrossRef] [PubMed]

118. Turathum, B.; Saikhun, K.; Sangsuwan, P.; Kitiyanant, Y. Effects of vitrification on nuclear maturation, ultrastructural changes and gene expression of canine oocytes. Reprod. Biol. Endocrinol. 2010, 8, 70. [CrossRef] [PubMed]

119. Abe, Y.; Asano, T.; Ali, M.; Suzuki, H. Vitrification of canine cumulus-oocyte complexes in DAP213 with a cryotop holder. Reprod. Med. Biol. 2010, 9, 115-120. [CrossRef] [PubMed]

120. Boutelle, S.; Lenahan, K.; Krisher, R.; Bauman, K.L.; Asa, C.S.; Silber, S. Vitrification of oocytes from endangered Mexican gray wolves (Canis lupus baileyi). Theriogenology 2011, 75, 647-654. [CrossRef]

121. Zhou, G.B.; Ma, C.B.; Liu, G.S.; Zhu, S.E.; Zhang, H.H.; Jia, L.L.; Suo, L.; Shi, J.M.; Wang, Y.B.; Tian, J.H.; et al. Vitrification of farmed blue fox oocytes in ethylene glycol and DMSO-based solutions using open-pulled straw (OPS). CryoLetters 2009, 30, 112-118.

122. Gómez, M.C.; Pope, E.; Harris, R.; Mikota, S.; Dresser, B.L. Development of In Vitro matured, In Vitro fertilized domestic cat embryos following cryopreservation, culture and transfer. Theriogenology 2003, 60, 239-251. [CrossRef]

123. Pope, C.E.; Gómez, M.C.; Dresser, B.L. In vitro production and transfer of cat embryos in the 21st century. Theriogenology 2006, 66, 59-71. [CrossRef] [PubMed]

124. Sananmuang, T.; Tharasanit, T.; Nguyen, C.; Phutikanit, N.; Techakumphu, M. Culture medium and embryo density influence on developmental competence and gene expression of cat embryos. Theriogenology 2011, 75, 1708-1719. [CrossRef] [PubMed]

125. Kanda, M.; Miyazaki, T.; Kanda, M.; Nakao, H.; Tsutsui, T. Development of In Vitro fertilized feline embryos in a modified Earle's balanced salt solution: Influence of protein supplements and culture dishes on fertilization success and blastocyst formation. J. Vet. Med. Sci. 1998, 60, 423-431. [CrossRef] [PubMed]

126. Freistedt, P.; Stojkovic, M.; Wolf, E. Efficient In Vitro production of cat embryos in modified synthetic oviduct fluid medium: Effects of season and ovarian status. Biol. Reprod. 2001, 65, 9-13. [CrossRef]

127. Herrick, J.R.; Bond, J.B.; Magarey, G.M.; Bateman, H.L.; Krisher, R.L.; Dunford, S.A.; Swanson, W.F. Toward a feline-optimized culture medium: Impact of ions, carbohydrates, essential amino acids, vitamins, and serum on development and metabolism of In Vitro fertilization-derived feline embryos relative to embryos grown in vivo. Biol. Reprod. 2007, 76, 858-870. [CrossRef]

128. Comizzoli, P.; Wildt, D.E.; Pukazhenthi, B.S. Impact of anisosmotic conditions on structural and functional integrity of cumulusoocyte complexes at the germinal vesicle stage in the domestic cat. Mol. Reprod. Dev. 2008, 75, 345-354. [CrossRef]

129. Luvoni, G.C.; Pellizzari, P. Embryo development In Vitro of cat oocytes cryopreserved at different maturation stages. Theriogenology 2000, 53, 1529-1540. [CrossRef]

130. Sowińska, N.; Zahmel, J.; Niżański, W.; Hribal, R.; Fernandez-Gonzalez, L.; Jewgenow, K. Meiotic status does not affect the vitrificatione Effectiveness of domestic cat oocytes. Animals 2020, 10, 1371. [CrossRef]

131. Fernandez-Gonzalez, L.; Huebinger, J.; Jewgenow, K. Comparison of different materials for self-pressurized vitrification of feline oocytes-first results. Animals 2021, 11, 1314. [CrossRef] [PubMed] 
132. Fernandez-Gonzalez, L.; Jewgenow, K. Cryopreservation of feline oocytes by vitrification using commercial kits and slush nitrogen technique. Reprod. Domest. Anim. 2017, 52 (Suppl. 2), 230-234. [CrossRef]

133. Cocchia, N.; Ciani, F.; Russo, M.; El Rass, R.; Rosapane, I.; Avallone, L.; Tortora, G.; Lorizio, R. Immature cat oocyte vitrification in open pulled straws (OPSs) using a cryoprotectant mixture. Cryobiology 2010, 60, 229-234. [CrossRef]

134. Nowak, A.; Kochan, J.; Świętek, E.; Kij, B.; Prochowska, S.; Witarski, W.; Bugno-Poniewierska, M.; Niżański, W. Survivability and developmental competences of domestic cat (Felis catus) oocytes after Cryotech method vitrification. Reprod. Domest. Anim. 2020, 55, 992-997. [CrossRef] [PubMed]

135. Arayatham, S.; Tiptanavattana, N.; Tharasanit, T. Effects of vitrification and a Rho-associated coiled-coil containing protein kinase 1 inhibitor on the meiotic and developmental competence of feline oocytes. J. Reprod. Dev. 2017, 63, 511-517. [CrossRef]

136. Younis, A.; Toner, M.; Albertini, D.; Biggers, J. Cryobiology of non-human primate oocytes. Hum. Reprod. 1996, 11, 156-165. [CrossRef]

137. VandeVoort, C.A.; Leibo, S. Effect of cooling and exposure to ethylene glycol on In Vitro maturation and embryo development of rhesus oocytes. CryoLetters 2005, 26, 305-312. [PubMed]

138. VandeVoort, C.A.; Shirley, C.R.; Hill, D.L.; Leibo, S. Effects of cryoprotectants and cryopreservation on germinal vesicle-stage cumulus-oocyte complexes of rhesus monkeys. Fertil. Steril. 2008, 90, 805-816. [CrossRef]

139. Paynter, S.; Cooper, A.; Gregory, L.; Fuller, B.; Shaw, R. Permeability characteristics of human oocytes in the presence of the cryoprotectant dimethylsulphoxide. Hum. Reprod. 1999, 14, 2338-2342. [CrossRef]

140. Fuller, B. The permeability of unfertilised oocytes to 1,2 propanediol-a comparison of mouse and human cells. CryoLetters 1992, 7, 287-292.

141. Gook, D.A.; Osborn, S.M.; Johnston, W. Cryopreservation of mouse and human oocytes using 1, 2-propanediol and the configuration of the meiotic spindle. Hum. Reprod. 1993, 8, 1101-1109. [CrossRef]

142. Gook, D.A.; Osborn, S.M.; Bourne, H.; Johnston, W. Fertilization of human oocytes following cryopreservation; normal karyotypes and absence of stray chromosomes. Hum. Reprod. 1994, 9, 684-691. [CrossRef]

143. Yang, D. A successful human oocyte crypreservation regime: Survival, implantation and pregnancy rates are comparable to that of cryopreserved embryos generated from sibling oocytes. Fertil. Steril. 1999, 72, S86.

144. Boldt, J.; Cline, D.; McLaughlin, D. Human oocyte cryopreservation as an adjunct to IVF-embryo transfer cycles. Hum. Reprod. 2003, 18, 1250-1255. [CrossRef] [PubMed]

145. Monzo, C.; Haouzi, D.; Roman, K.; Assou, S.; Dechaud, H.; Hamamah, S. Slow freezing and vitrification differentially modify the gene expression profile of human metaphase II oocytes. Hum. Reprod. 2012, 27, 2160-2168. [CrossRef] [PubMed]

146. Pensis, M.; Loumaye, E.; Psalti, I. Screening of conditions for rapid freezing of human oocytes: Preliminary study toward their cryopreservation. Fertil. Steril. 1989, 52, 787-794. [CrossRef]

147. Kuleshova, L.; Gianaroli, L.; Magli, C.; Ferraretti, A.; Trounson, A. Birth following vitrification of a small number of human oocytes: Case report. Hum. Reprod. 1999, 14, 3077-3079. [CrossRef]

148. De Munck, N.; Vajta, G. Safety and efficiency of oocyte vitrification. Cryobiology 2017, 78, 119-127. [CrossRef]

149. Isachenko, V.; Montag, M.; Isachenko, E.; Zaeva, V.; Krivokharchenko, I.; Shafei, R.; Van der Ven, H. Aseptic technology of vitrification of human pronuclear oocytes using open-pulled straws. Hum. Reprod. 2005, 20, 492-496. [CrossRef] [PubMed]

150. Khalili, M.A.; Maione, M.; Palmerini, M.G.; Bianchi, S.; Macchiarelli, G.; Nottola, S.A. Ultrastructure of human mature oocytes after vitrification. Eur. J. Histochem. EJH 2012, 56, e38. [CrossRef]

151. Nottola, S.; Macchiarelli, G.; Coticchio, G.; Bianchi, S.; Cecconi, S.; De Santis, L.; Scaravelli, G.; Flamigni, C.; Borini, A. Ultrastructure of human mature oocytes after slow cooling cryopreservation using different sucrose concentrations. Hum. Reprod. 2007, 22, 1123-1133. [CrossRef]

152. Nottola, S.A.; Coticchio, G.; De Santis, L.; Macchiarelli, G.; Maione, M.; Bianchi, S.; Iaccarino, M.; Flamigni, C.; Borini, A. Ultrastructure of human mature oocytes after slow cooling cryopreservation with ethylene glycol. Reprod. Biomed. Online 2008, 17, 368-377. [CrossRef]

153. Mullen, S.F.; Li, M.; Li, Y.; Chen, Z.-J.; Critser, J.K. Human oocyte vitrification: The permeability of metaphase II oocytes to water and ethylene glycol and the appliance toward vitrification. Fertil. Steril. 2008, 89, 1812-1825. [CrossRef]

154. Di Pietro, C.; Vento, M.; Guglielmino, M.; Borzì, P.; Santonocito, M.; Ragusa, M.; Barbagallo, D.; Duro, L.; Majorana, A.; De Palma, A. Molecular profiling of human oocytes after vitrification strongly suggests that they are biologically comparable with freshly isolated gametes. Fertil. Steril. 2010, 94, 2804-2807. [CrossRef] [PubMed]

155. Huo, Y.; Yuan, P.; Qin, Q.; Yan, Z.; Yan, L.; Liu, P.; Li, R.; Yan, J.; Qiao, J. Effects of vitrification and cryostorage duration on single-cell RNA-Seq profiling of vitrified-thawed human metaphase II oocytes. Front. Med. 2021, 15, 144-154. [CrossRef] [PubMed]

156. De Munck, N.; Petrussa, L.; Verheyen, G.; Staessen, C.; Vandeskelde, Y.; Sterckx, J.; Bocken, G.; Jacobs, K.; Stoop, D.; De Rycke, M. Chromosomal meiotic segregation, embryonic developmental kinetics and DNA (hydroxy) methylation analysis consolidate the safety of human oocyte vitrification. Mhr Basic Sci. Reprod. Med. 2015, 21, 535-544. [CrossRef]

157. Li, J.; Yang, X.; Liu, F.; Song, Y.; Liu, Y. Evaluation of differentially expressed microRNAs in vitrified oocytes by next generation sequencing. Int. J. Biochem. Cell Biol. 2019, 112, 134-140. [CrossRef]

158. Comizzoli, P.; Holt, W.V. Recent advances and prospects in germplasm preservation of rare and endangered species. Adv. Exp. Med. Biol. 2014, 753, 331-356. [CrossRef] 
159. Konc, J.; Kanyó, K.; Kriston, R.; Somoskői, B.; Cseh, S. Cryopreservation of embryos and oocytes in human assisted reproduction. Biomed. Res. Int. 2014, 2014, 307268. [CrossRef]

160. Ethics Committee of the American Society for Reproductive Medicine. Fertility preservation and reproduction in patients facing gonadotoxic therapies: A committee opinion. Fertil. Steril. 2013, 100, 1224-1231. [CrossRef]

161. Martinez, F.; Andersen, C.Y.; Barri, P.; Brannigan, R.; Cobo, A.; Donnez, J.; Dolmans, M.M.; Evers, J.H.; Feki, A.; Goddijn, M Update on fertility preservation from the Barcelona International Society for Fertility Preservation-ESHRE-ASRM 2015 expert meeting: Indications, results and future perspectives. Fertil. Steril. 2017, 108, 407-415.e411. [CrossRef]

162. Cobo, A.; Garcia-Velasco, J.A.; Domingo, J.; Remohí, J.; Pellicer, A. Is vitrification of oocytes useful for fertility preservation for age-related fertility decline and in cancer patients? Fertil. Steril. 2013, 99, 1485-1495. [CrossRef] [PubMed]

163. Sackmann, E.K.; Fulton, A.L.; Beebe, D.J. The present and future role of microfluidics in biomedical research. Nature 2014, 507, 181-189. [CrossRef] [PubMed]

164. Heo, Y.S.; Lee, H.-J.; Hassell, B.A.; Irimia, D.; Toth, T.L.; Elmoazzen, H.; Toner, M. Controlled loading of cryoprotectants (CPAs) to oocyte with linear and complex CPA profiles on a microfluidic platform. Lab. Chip 2011, 11, 3530-3537. [CrossRef] [PubMed]

165. Le Gac, S.; Ferraz, M.; Venzac, B.; Comizzoli, P. Understanding and Assisting Reproduction in Wildlife Species Using Microfluidics. Trends Biotechnol. 2021, 39, 584-597. [CrossRef] [PubMed]

166. Anifandis, G.; Messini, C.I.; Simopoulou, M.; Sveronis, G.; Garas, A.; Daponte, A.; Messinis, I.E. SARS-CoV-2 vs. human gametes, embryos and cryopreservation. Syst. Biol. Reprod. Med. 2021, 64, 260-269. [CrossRef] [PubMed]

167. Reis, F.M.; Bouissou, D.R.; Pereira, V.M.; Camargos, A.F.; dos Reis, A.M.; Santos, R.A. Angiotensin-(1-7), its receptor Mas, and the angiotensin-converting enzyme type 2 are expressed in the human ovary. Fertil. Steril. 2011, 95, 176-181. [CrossRef]

168. Barragan, M.; Guillén, J.; Martin-Palomino, N.; Rodriguez, A.; Vassena, R. Undetectable viral RNA in oocytes from SARS-CoV-2 positive women. Hum. Reprod. 2021, 36, 390-394. [CrossRef]

169. Demirel, C.; Tulek, F.; Celik, H.G.; Donmez, E.; Tuysuz, G.; Gökcan, B. Failure to detect viral RNA in follicular fluid aspirates from a SARS-CoV-2-positive woman. Reprod. Sci. 2021, 8, 2144-2146. [CrossRef]

170. Porcu, E.; Tranquillo, M.L.; Notarangelo, L.; Ciotti, P.M.; Calza, N.; Zuffa, S.; Mori, L.; Nardi, E.; Dirodi, M.; Cipriani, L. High-security closed devices are efficient and safe to protect human oocytes from potential risk of viral contamination during vitrification and storage especially in the COVID-19 pandemic. J. Assist. Reprod. Genet. 2021, 38, 681-688. [CrossRef] 